\title{
Contribution of Good Governance Principles to Strengthening Zakat Management in Indonesia: Confirmatory Factor Analysis
}

\author{
Hani Tahliani \\ PT Pendidikan Maritim \& Logistik Indonesia \\ (IPC Corporate University)
}

\begin{abstract}
Good governance is a crucial issue in strengthening the performance of zakat institutions. This research aims to elaborate good governance from the perspective of Islam and analyze the factors contributing to good corporate governance in a number of zakat institutions in Indonesia. Confirmatory Factor Analysis (CFA) is employed to measure the contribution of each indicator to the five principles of good governance in zakat institutions, namely transparency, accountability, responsibility, independence, and fairness. With the assistance of Partial Least Squares (PLS) version 3 it is shown that the principle of transparency contributes $60.4 \%$; the principle of accountability $4.82 \%$; the principle of responsibility $6.41 \%$; and the principle of independence $53.3 \%$. Therefore, it can be concluded that good governance in zakat institutions has been well implemented in some aspects but has not yet been implemented comprehensively. This research is significant in that it contributes guidelines on zakat management, provides teaching materials for higher education, and serves as a reference for the formulation of policies and regulations related to the standardization of good governance in zakat institutions.
\end{abstract}

Keywords: Good Governance, Zakat Institutions, Performance, Confirmatory Factor Analysis (CFA)

\section{INTRODUCTION}

Good governance is a crucial issue in the context of strengthening the performance of zakat institutions. As public organizations, the performance of zakat institutions, notably in relation to their management and service, serves as a benchmark for the growth of public trust. The urgency of implementation of good governance in various public institutions aims to promote their effective and efficient management in order to protect the interests of the board of directors, management, staff, stakeholders, shareholders, and customers. The principles of transparency, accountability, responsibility, independence, and fairness are the dimensions shaping the framework in terms of the achievement of good governance in public institutions.
As public entities, zakat institutions are expected to perform well, especially in their role of providing a service to the poor and underprivileged. Zakat institutions are a pivotal instrument in the concept and system of an Islamic economy, especially in terms of their role of redistributing wealth from the rich (muzakki) to the poor (dhuafa). As an Islamic institution, the zakat institution should comply with the ethical and moral values of Islam. The principles of amanah (trustworthiness), transparency, accountability, and sharia compliance are among the characteristics that differentiate zakat institutions from conventional institutions. Islam contains no specific concepts related to corporate governance but it does feature ethical and moral values that can be constructed as a framework for good governance. As 
explained by Bhatti and Bhatti (2010) in their study "Development in Legal Issues of Corporate Governance in Islamic Finance," Islamic legal approaches and business ethics based on maqashid sharia (the noble purposes of sharia) provide a framework for Islamic corporate governance. The basic principles adopted from Islamic values that support this framework are as follows: the concepts of hisbah, shura (shuratic decision-making process), disclosure and transparency, bookkeeping and final accounts, and religious audit. These values can be used to formulate policies and regulations for Islamic institutions, thereby helping to achieve good corporate governance (GCG).

In the context of zakat management in Indonesia, Islamic values have been incorporated into a specific law, namely Law No. 23 Year 2011 on Zakat Management. Based on this law, there are two models of zakat management in Indonesia: (1) Zakat managed by the State through specific government bodies, and (2) Zakat managed by nongovernmental organizations (Jahar, 2008). In accordance with the law, zakat in Indonesia should be managed professionally based on the values and principles of good governance. Good governance in zakat management is a system for organizing and controlling the company to create value added for all stakeholders (Sedarmayanti, 2007). Professional management is expected to improve the performance of zakat institutions in Indonesia by maximizing their potential. Based on research conducted by IPB, Indonesia has the potential to collect an annual zakat amount equal to IDR 217 trillion. The Chairman of the National Zakat Management Board (BAZNAS), Bambang Sudibyo, mentioned that with several adjustments, BAZNAS estimated the potential value of zakat nationally to have risen from IDR 217 trillion to IDR 274 trillion (Sudibyo, 2016). Unfortunately, however, this potential is not being realized. Based on data from BAZNAS, the actual amount of zakat collected at the national level is an estimated IDR 3-4 trillion per year. In response to this situation, Irfan Syauqi Beik (2009), on the one hand, has stated that a number of government policies are not yet effective in terms of realizing the full potential value of zakat. On the other hand, however, there is no specific regulation that provides guidelines for measuring good governance in Indonesian zakat institutions. As a result, good governance continues to be interpreted differently by different zakat management institutions, especially in relation to the various individual indicators that they apply. In other words, good governance is being undertaken only partially and in a sporadic manner. This therefore makes it urgent to study the implementation of good governance in a number of Indonesian zakat institutions. This research focuses on analyzing the factors contributing to good governance in several Indonesian zakat institutions. These factors can be used as a reference in designing standards of good governance in Indonesian zakat institutions with the aim of improving their performance.

Research on zakat has been conducted by various Muslim scholars. Norazlina and Abdul Rahim (2011) set out their findings in an article entitled "The Framework Efficiency of Zakat Institutions in Malaysia: An application of data envelopment analysis." The results of their research showed that zakat institutions in Malaysia have an average efficiency of $80.6 \%$. Using the Spearmen and Pearson correlation models, they also determined that in a number of countries, a high Muslim population is positively correlated with zakat collection and turnout. Samra (2016), in a study titled "Corporate Governance in Islamic Financial Institutions," showed that corporate governance has become a major issue since leading business institutions' failure to implement it to a good standard has been a major cause of their general failure. The enforcement of good governance principles in an integrated manner is essential to 
business institutions as it allows them to compete on a more global basis, to meet the demands of investors and policymakers, and to serve their customers better. Furthermore, for Islamic financial institutions specifically, corporate governance is important to aid them in competing with conventional financial institutions.

Chapra and Ahmed (2002) conducted a survey on corporate governance in various Islamic institutions at three levels, namely those of the regulator, Islamic bank, and depositors. In their view, the growth and development of Islamic banking requires good governance so that it can reach large financial-sector markets and in order to promote moral integrity in managing and using funds. Corporate governance is implemented via a range of specific mechanisms and instruments that promote effective and accountable managerial performance in order to maximize benefits for shareholders and customers. In this context, all functions will run well, including internal surveillance, risk management, transparency, accountability, fairness, sharia compliance, external audit, regulation, and supervision enforcement. The existing research on good governance focuses more on Islamic financial institutions than on non-financial institutions such as zakat institutions. In contrast to other research, this article takes a different approach to analyzing the implementation of good governance in zakat institutions, namely that of Confirmatory Factor Analysis (CFA). This approach is used to identify the factors that contribute to good governance in a number of Indonesian zakat institutions. The study aims to enrich perspectives on GCG in zakat institutions on a theoretical level. It also aims to serve as a teaching resource reference for universities, especially on the subject of zakat, as well as a reference for policymakers in developing regulations on good governance for zakat institutions.

\section{LITERATURE REVIEW}

There have been numerous studies conducted on GCG from an Islamic perspective. These include the following: 1) Studies on good governance from an Islamic perspective conceptually by Lewis (2005: 5-29), Bhatti (2009:67-91), and Hasan (2009: 277-293). These authors state that Islamic corporate governance has its own unique features and distinctive characteristics in comparison with the western concept. It combines elements of Tauhid, Shura, and Shari'ah principles and seeks to achieve private goals without neglecting social welfare duty. 2) Studies on corporate governance in Islamic financial institutions by Samra (2016), Chapra and Ahmed (2002), and Wafiq and Pellegrim (2006). These studies demonstrate how corporate governance has become a major issue for Islamic financial institutions due to their failure to implement GCG. 3) Studies on Islamic governance in social organizations by Issyam et al. (2016), specifically on a sharia governance framework for Islamic co-operatives, Ramli and Muhammad (2013), on a good governance framework for corporate waqf, and Wahab and Rahman (2011) on the governance of zakat institutions in Malaysia. These prior studies demonstrate that Sharia governance is essential for enhancing the performance of the management of Islamic institutions. Unlike other studies, this study analyzes the implementation of GCG in zakat management regulation in Indonesian. It also develops and proposes a conceptual model to formulate the Sharia governance standard of zakat institutions.

\section{METHODS}

This research involves both the collection of qualitative data and the quantitative statistical analysis of data (Hermawan, 2003). The statistical analysis applies the Second Order Confirmatory Factor 
Analysis (CFA) measurement model, which consists of two levels. At the first level, confirmatory factor analysis demonstrates the connections between variables as indicators of related latent variables. At the second level, confirmatory factor analysis demonstrates the connections between the latent variables at the first level as indicators of latent variables at the second level. The confirmatory factor analysis modeling in this research examines the contribution made by each indicator to the dimensions of GCG and measures the contribution of each dimension, namely the principles of transparency, accountability, responsibility, independence, and fairness, to the realization of the principle of Good Governance with the assistance of Partial Least Squares (PLS) version 3.

This research uses a structured questionnaire where respondents choose from a series of answers. The questionnaire comprises 27 indicators classified in accordance with the five principles of Good Governance; namely, (1) transparency, (2) accountability, (3) responsibility, (4) independence, and (5) fairness. These principles are taken from various sources and theories adapted from previous research. The respondents in this research are leaders and staff of zakat institutions. A purposive sampling method is used, namely non-probabilistic sampling, based on certain criteria or considerations (Masri Mansoer, 2009). Out of ten existing zakat institutions, only four were willing to share their data and information. These were BAZIS Jakarta Capital Region, BAZNAS Municipality of Bogor, BAZNAS District of Karawang, and BAMUIS BNI.

\section{RESULTS AND DISCUSSION}

Questionnaires were distributed to all staff of the zakat institutions, from the directorates to lower-level staff, in all four of the zakat institutions that agreed to participate. Over a period of three weeks, a total of 55 questionnaires were distributed, with a total of 42 completed and returned. Of these 42, however, 2 were not suitable for data processing and analysis. In total, 40 questionnaires were put forward for data processing and analysis. The 40 questionnaires taken forward to the data processing stage contained the responses from four zakat institutions. BAZIS DKI returned 20 questionnaires $(50 \%$ of the total). BAZNAS Municipality of Bogor returned 9 questionnaires (22.5\%). BAZNAS District of Karawang returned 6 questionnaires (15\%), while BAMUIS BNI returned 5 questionnaires $(12.5 \%)$. The criteria for selecting the institutions were that they were legally recognized, had been operating for more than five years, and were willing to participate as respondents in the research.

\section{Building the Theory-Based Model}

Using the CFA method (Harrington, 2009), GCG in this research is identified as the exogenous latent variable, which is a second-stage factor not measured by the indicator. The five principles of $\mathrm{GCG}$ (transparency, accountability, responsibility, independence, and fairness) are identified as the endogenous latent variables and become the first-stage factors, with the five dimensions of these first-stage factors measured using the 27 indicators as shown in Table 1.

Table 1. Research Instrument

\begin{tabular}{|c|c|l|c|c|}
\hline Variable & Dimension & \multicolumn{1}{|c|}{ Indicator } & $\begin{array}{l}\text { Item } \\
\text { Code }\end{array}$ & Item Number \\
\hline & Transparency & $\begin{array}{l}\text { Mechanism of openness and } \\
\text { standardization of all processes. }\end{array}$ & i1x1 & $1-9$ \\
\hline
\end{tabular}




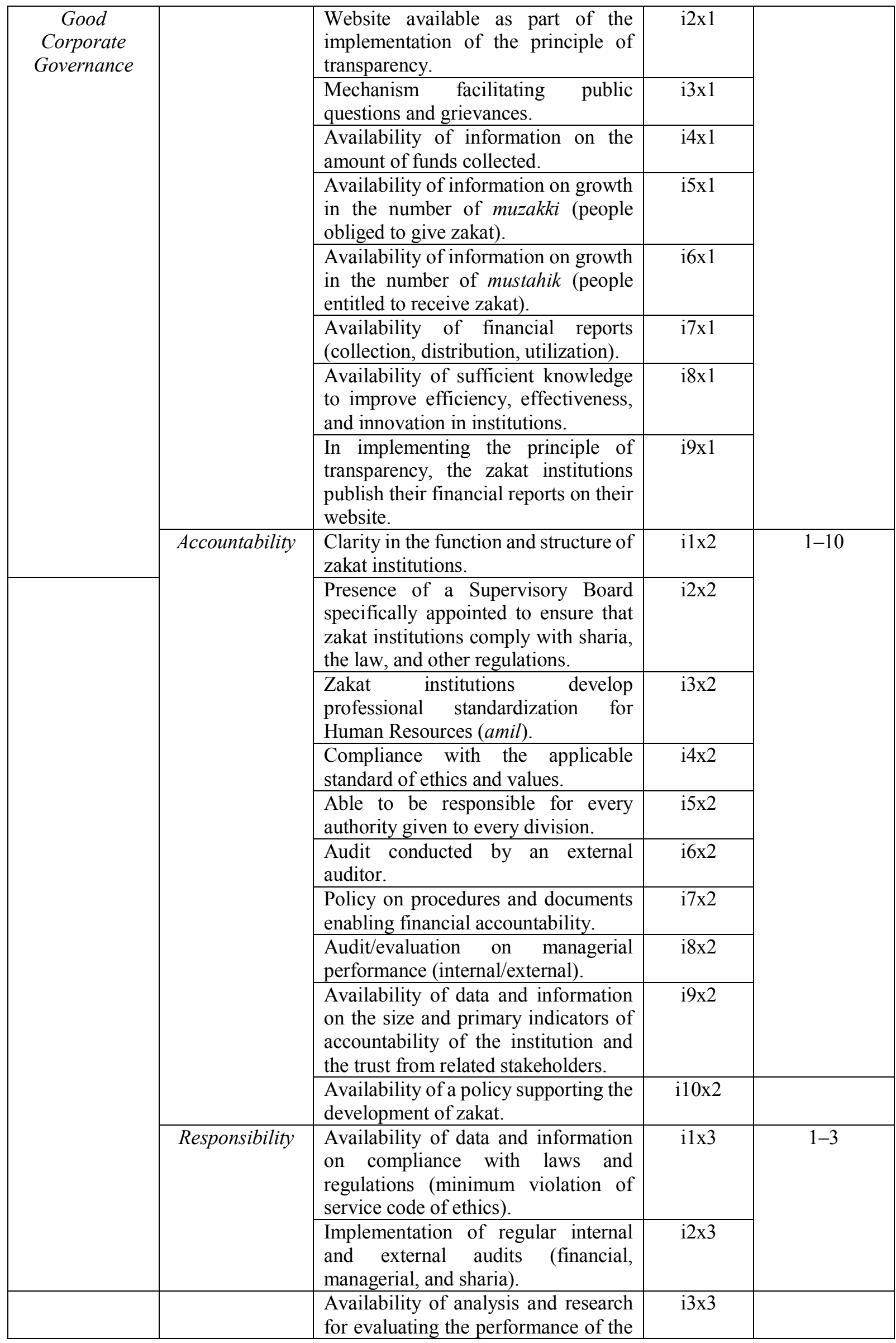




\begin{tabular}{|c|c|c|c|}
\hline & $\begin{array}{l}\text { institution for the purpose of } \\
\text { improving it. }\end{array}$ & & \\
\hline \multirow[t]{3}{*}{ Independence } & $\begin{array}{l}\text { Professional management of zakat } \\
\text { institutions. }\end{array}$ & i1x4 & \multirow[t]{3}{*}{$1-3$} \\
\hline & $\begin{array}{l}\text { No pressure from unauthorized parties } \\
\text { based on existing regulations. }\end{array}$ & $\mathrm{i} 2 \mathrm{x} 4$ & \\
\hline & $\begin{array}{l}\text { Objective and independent decision- } \\
\text { making, free from pressure or } \\
\text { intimidation from any party. }\end{array}$ & $\mathrm{i} 3 \mathrm{x} 4$ & \\
\hline \multirow[t]{2}{*}{ Fairness } & $\begin{array}{l}\text { Fairness for all stakeholders (Human } \\
\text { Resources, Muzakki, Mustahik). }\end{array}$ & i1x5 & \multirow[t]{2}{*}{$1-2$} \\
\hline & $\begin{array}{l}\text { Zakat institution provides } \\
\text { opportunities for all stakeholders to } \\
\text { provide their input and suggestions for } \\
\text { the betterment of the institution. }\end{array}$ & i1x5 & \\
\hline
\end{tabular}

Source: Taken from Various Sources

Results of Estimation Parameter and Path Diagram

A CFA path diagram in two levels is presented below, along with the parameter of result estimation that describes the connections between the indicators and dimensions of transparency, accountability, responsibility, independence, and fairness. It also describes the connection between the five dimensions and the implementation of good governance. An indicator is said to be valid at first order CFA and second order CFA if it has a loading score greater than 0.5. A loading score of less than 0.5 means that the indicator will be erased as it cannot be loaded to the construct representing it (Abdillah \& Jogiyanto, 2015).

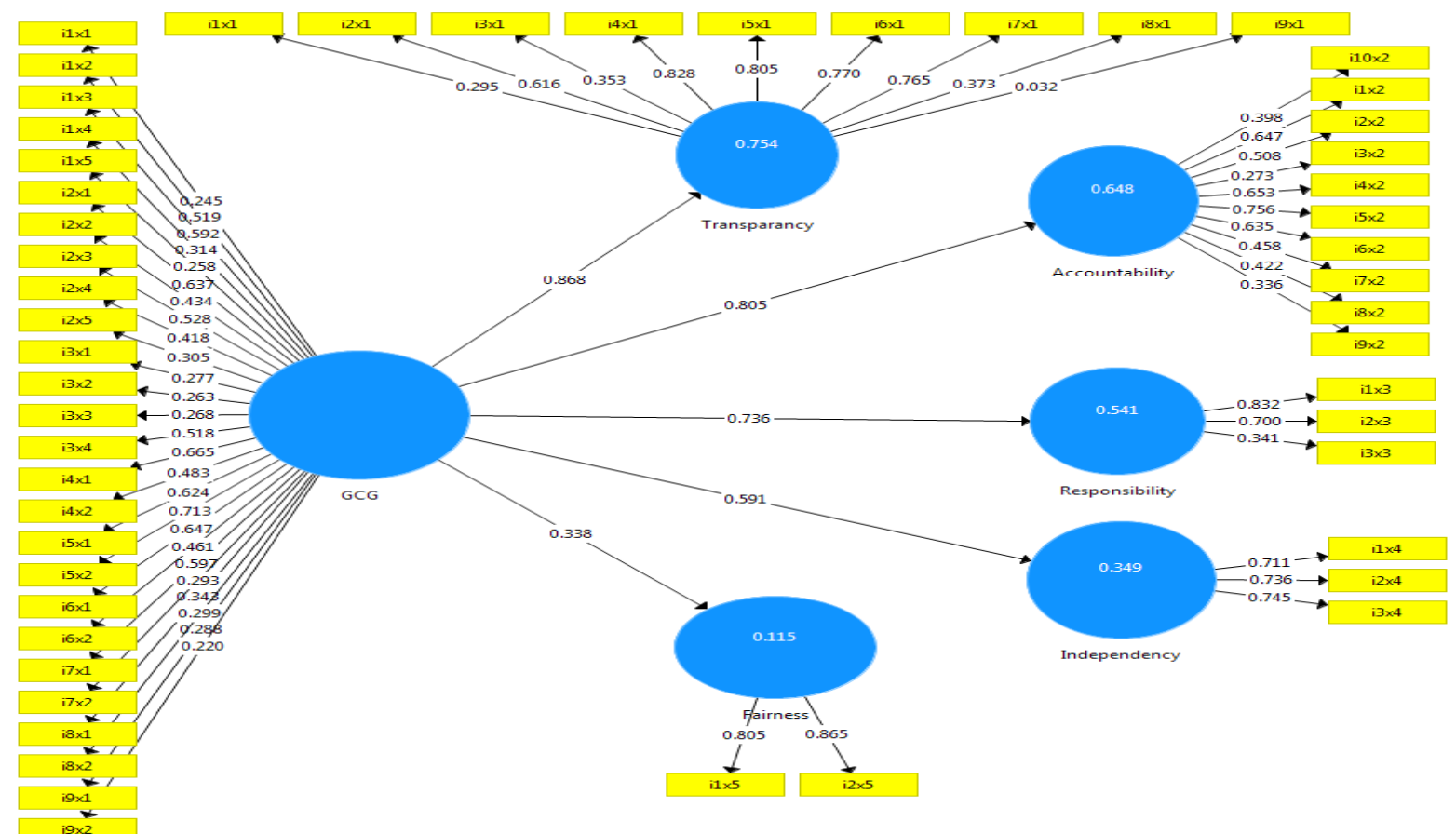

Figure 1. Path Diagram Results of Estimation Parameter

The path diagram in Figure 1 above shows that at first order CFA, a total of 10 indicators have a loading score of less than
0.5 , namely (i1x $1, \mathrm{i} 3 \times 1, \mathrm{i} 8 \mathrm{x} 1, \mathrm{i} 9 \mathrm{x} 1, \mathrm{i} 3 \mathrm{x} 2$, $\mathrm{i} 7 \times 2$, i8x2, i9x2, i10x2, and i3x3). At second order CFA, there is only one 
construct, in the dimension of fairness, with a loading score of less than 0.5 . Hence, there are 10 indicators that are not valid for first order CFA that must be removed from the analysis. At second order $C F A$, there is one specific dimension (fairness) with a loading score below 0.5 and two other indicators that are also erased from the model because of their weakness in explaining the construct. Hence, re-running must be done. Figure 2 shows the result of running the path diagram on the result of the estimation parameter.

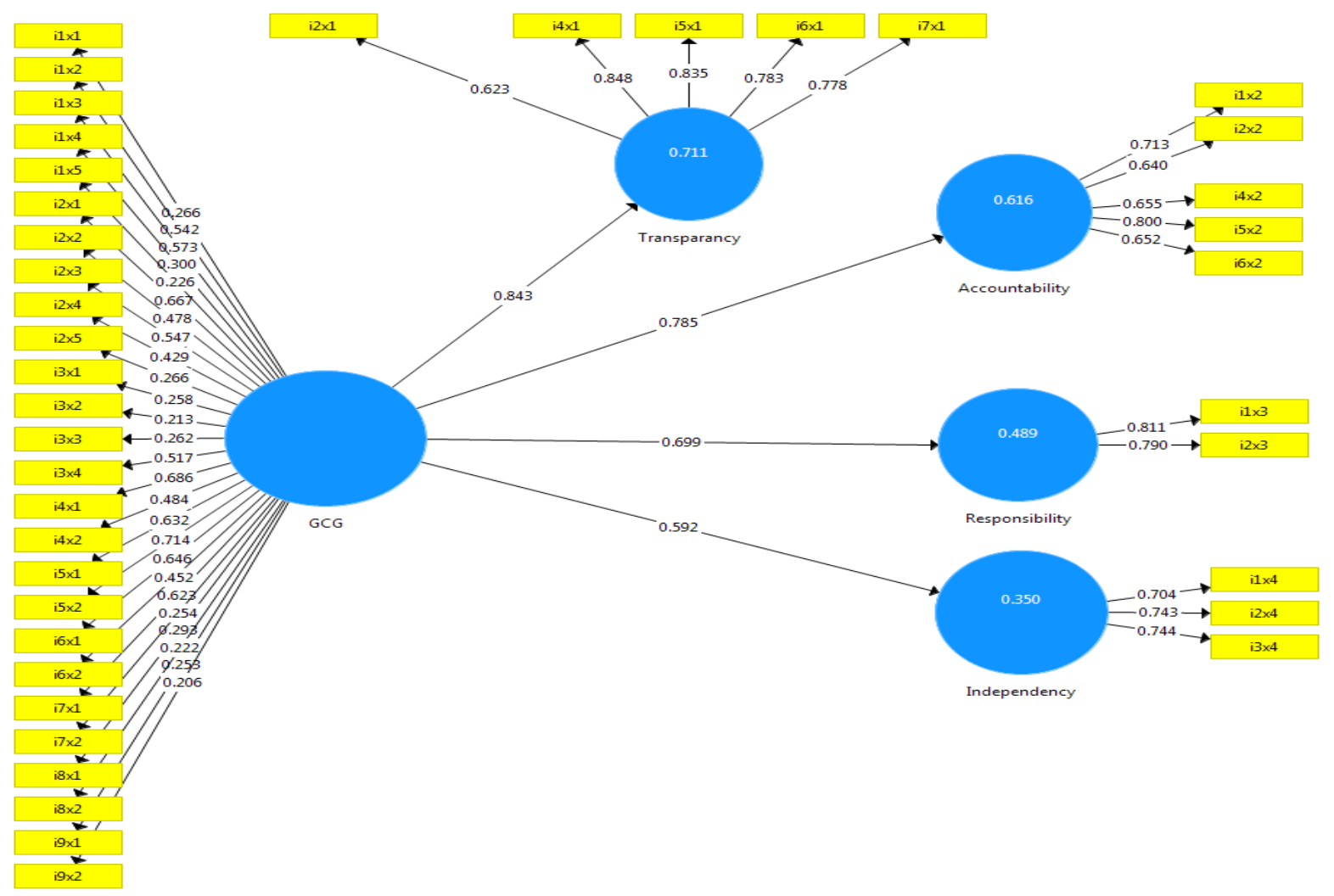

Figure 2. Test Running the Path Diagram Result of Estimation Parameter

Source: Output Smart PLS Version 3 (Student Version)

In Figure 2, the test running the path diagram result of estimation parameter shows that all of the indicators and constructs related to the dimensions of transparency, accountability, responsibility, and independence have a loading score above 0.5 . This means that all of the indicators and constructs are valid. It can thus be concluded that the observed variables are able to measure the constructs well.

\section{Estimation of the Outer Model}

The Outer Model is a test model that includes the validity and reliability model. To test the validity of the outer model, the study uses the following hypotheses: Ho = insignificant/invalid loading factor parameter coefficient, and $\mathrm{Ha}=$ significant/valid loading factor parameter coefficient. With test criteria using statistic test $t$, if the $t$ count $\geq t$ table (1.96), then Ho is rejected, and if the $\mathrm{t}$ count $\leq \mathrm{t}$ table (1.96), then Ho is accepted. As for the reliability test, it is indicated by two measurements, namely Composite Reliability (CR) and Average Variance Extracted (AVE). A construct (latent variable) has good reliability if the $C R$ score is $\geq 0.7$ and the AVE score is $\geq 0.5$. The following table describes the output of the statistical scores on the standardized loading factor and statistic $t$ count. 
Table 2. Outer Model

\begin{tabular}{|c|c|c|c|}
\hline Variable & Loading Factor & $\mathbf{t}_{\text {test }}$ & . \\
\hline \multicolumn{4}{|l|}{ 1st CFA } \\
\hline \multicolumn{4}{|c|}{ Transparency } \\
\hline $\mathrm{i} 2 \mathrm{x} 1$ & 0.623 & 3.076 & Valid \\
\hline i4x1 & 0.848 & 5.141 & Valid \\
\hline $\mathrm{i} 5 \mathrm{x} 1$ & 0.835 & 4.383 & Valid \\
\hline i6x1 & 0.783 & 4.949 & Valid \\
\hline i7x1 & 0.778 & 7.124 & Valid \\
\hline \multicolumn{4}{|c|}{ Accountability } \\
\hline i1x2 & 0.713 & 2.875 & Valid \\
\hline $\mathrm{i} 2 \times 2$ & 0.640 & 2.381 & Valid \\
\hline $\mathrm{i} 4 \times 2$ & 0.655 & 3.190 & Valid \\
\hline $\mathrm{i} 5 \times 2$ & 0.800 & 4.943 & Valid \\
\hline i6x2 & 0.652 & 2.013 & Valid \\
\hline \multicolumn{4}{|c|}{ Responsibility } \\
\hline i1 $1 \times 3$ & 0.811 & 3.946 & Valid \\
\hline$i 2 \times 3$ & 0.790 & 2.684 & Valid \\
\hline \multicolumn{4}{|c|}{ Independence } \\
\hline $\mathrm{i} 1 \mathrm{x} 4$ & 0.704 & 2.743 & Valid \\
\hline $\mathrm{i} 2 \mathrm{x} 4$ & 0.743 & 2.116 & Valid \\
\hline$i 3 \times 4$ & 0.744 & 3.178 & Valid \\
\hline \multicolumn{4}{|l|}{ 2nd CFA } \\
\hline \multicolumn{4}{|l|}{ GCG } \\
\hline Transparency & 0.843 & 13.300 & Valid \\
\hline Accountability & 0.785 & 10.327 & Valid \\
\hline Responsibility & 0.699 & 7.032 & Valid \\
\hline Independence & 0.592 & 5.556 & Valid \\
\hline
\end{tabular}

Source: Output Smart PLS Version 3 (Student Version)

Table 2 shows that the standardized loading factor has a good validity, wherein the value of the $t$ factor load factor $>$ critical value ( $t$ count $>1.96$ ) and the value of the standardized loading factor $>0.5$. Therefore, it can be concluded that the observed variables are able to measure their constructs accurately. The next test, for convergent validity, relates to the reliability of the constructs by looking at their output for composite reliability. A criterion is said to be reliable when it has a composite reliability above 0.7 . The following is the Composite Reliability (CR) and Average Variance Extracted (AVE) scores of Good Governance at zakat institutions.

Table 3. Test on the Reliability of the Outer Model

\begin{tabular}{lccc}
\hline \multicolumn{1}{c}{ Construct } & $\begin{array}{c}\text { Composite Reliability } \\
(\mathbf{C R})\end{array}$ & $\begin{array}{c}\text { Average Variance } \\
\text { Extracted (AVE) }\end{array}$ & Summary \\
\hline \hline Transparency & 0.883 & 0.604 & Reliable \\
\hline Accountability & 0.822 & 0.582 & Reliable \\
\hline Responsibility & 0.782 & 0.641 & Reliable \\
\hline Independence & 0.774 & 0.533 & Reliable \\
\hline
\end{tabular}




\begin{tabular}{lccc}
\hline $\mathbf{2}^{\text {nd }}$ CFA & & \\
\hline GCG & 0.845 & 0.648 & Reliable \\
\hline Source: Output Smart PLS Version 3 (Student Version) & &
\end{tabular}

Table 3 shows that all of the CR scores of the four latent variables are above the benchmark of 0.7 . Hence, it can be concluded that the constructs have good reliability as a measuring instrument and their AVE scores are above the benchmark of 0.5. This indicates a fairly high level of reliability for each construct, which means that the indicators of each construct are consistent in measuring the construct.

\section{Estimation of the Inner Model}

After evaluating the outer model, the next step is to evaluate the inner model using the model purposed in respect of four dimensions (transparency, accountability, responsibility, independence). Evaluation of the compatibility of either the inner model or the entire model can be measured using $Q$-Square predictive relevance. The higher the $\mathrm{R}^{2}$ score, the better the predictive model of the research model purposed. According to Chin, an $\mathrm{R}^{2}$ score of 0.67 is categorized as substantial, an $\mathrm{R}^{2}$ score of 0.33 is categorized as moderate, and an $\mathrm{R}^{2}$ score of 0.19 is categorized as weak (Sarwono \& Narimawati, 2015). However, $\mathrm{R}^{2}$ is not an absolute parameter in measuring the precision of the prediction model since the basis of the theoretical relation is the primary parameter that explains this cause and effect relationship (Abdillah \& Jogiyanto, 2015). The following is the $\mathrm{R}^{2}$ score of each dimension (transparency, responsibility, independence).

Table 4. Inner Model Test

\begin{tabular}{cc}
\hline Construct & R-squared $\left(\mathbf{R}^{2}\right)$ \\
\hline \hline Transparency & 0.711 \\
\hline Accountability & 0.616 \\
\hline Responsibility & 0.489 \\
\hline Independence & 0.350 \\
\hline
\end{tabular}

Source: Output Smart PLS Version 3 (Student Version)

Following the outer model evaluation, the next step is to conduct the evaluation. Table 4 shows the results of the evaluation of the compatibility of the inner model, out of all models, measured using the $R$-squared score with the following formula:

$$
\begin{aligned}
\mathrm{Q}^{2}= & 1-\left(1-\mathrm{R}_{1}^{2}\right)\left(1-\mathrm{R}_{2}^{2}\right)\left(1-\mathrm{R}_{3}^{2}\right)\left(1-\mathrm{R}_{4}^{2}\right) \\
\mathrm{Q}^{2}= & 1-(1-0.711)(1-0.616)(1-0.489) \\
& (1-0.350) \\
\mathrm{Q}^{2}= & 0.9632
\end{aligned}
$$

The result shows that the $R$-squared score of the four principles of Good Governance produced a $\mathrm{Q}^{2}$ score that is close to 1 .
Therefore, it can be concluded that the compatibility of the inner model is good.

Outer Model Analysis of the Transparency Dimension

The Outer Model (first order CFA) is defined as a model for measuring the relationships between, and the relative contributions of, each indicator of the latent endogenous variable of Transparency. The results of the estimation of the standardized loading factor parameter for Transparency for the outer model based on the 5 indicators are as follows: 
Table 5. Standardized Loading Factor Scores on the Transparency Dimension

\begin{tabular}{clll}
\hline Dimension & Item & \multicolumn{1}{c}{ Indicator } & Score \\
\hline Transparency & $\mathrm{i} 2 \mathrm{x} 1$ & $\begin{array}{l}\text { Website available as part of the implementation of } \\
\text { the principle of transparency }\end{array}$ & 0.623 \\
\cline { 2 - 4 } & $\mathrm{i} 4 \mathrm{x} 1$ & $\begin{array}{l}\text { Availability of information on the amount of } \\
\text { funds collected }\end{array}$ & 0.848 \\
\cline { 2 - 4 } & $\mathrm{i}$ Availability of information on growth in the \\
& number of muzakki (people obliged to give zakat) & 0.835 \\
\cline { 2 - 4 } $\mathrm{i} 6 \mathrm{x} 1$ & $\begin{array}{l}\text { Availability of information on growth in the } \\
\text { number of mustahik (people entitled to receive } \\
\text { zakat) }\end{array}$ & 0.783 \\
& $\begin{array}{l}\text { Availability of financial reports (collection, } \\
\text { distribution, utilization) }\end{array}$ & 0.778 \\
\hline
\end{tabular}

Source: Output Smart PLS Smart version 3

Table 5 contains the loading scores of the 5 indicators for the dimension of Transparency. It can be seen that all 5 indicators provide valid and good contributions when measuring the dimension of Transparency. The following is an analysis of the levels of contribution by each indicator to the dimension (Transparency):

1) i $2 \times 1$ (Website available to implement the principle of transparency) contributes to the dimension of Transparency by as much as 0.623 .

2) $i 4 x 1$ (Availability of information on the amount of funds collected) contributes to the dimension of Transparency by as much as 0.848 .

3) i5x1 (Availability of information on growth in the number of muzakki (people obliged to give zakat)) contributes to the dimension of Transparency by as much as 0.835 .

4) i6x1 (Availability of information on growth in the number of mustahik (people entitled to receive zakat)) contributes to the dimension of Transparency as much as 0.783 .

5) $17 x 1$ (Availability of financial reports (collection, distribution, utilization)) contributes to the dimension of Transparency by as much as 0.778 .
For the dimension of Transparency, it can be seen that the indicator that contributes the most is i4x1 (Availability of information on the amount of funds collected), with a score of 0.848 . The lowest contribution is by $\mathrm{i} 7 \mathrm{x} 1$ (Availability of financial reports (collection, distribution, utilization)), with a score of 0.778 . Taken together, the total contribution of the 5 indicators in the outer model of transparency is as much as the AVE score. A previous calculation revealed an AVE score of 0.604 for the dimension of Transparency. This means that all 5 indicators applied to measure the dimension of Transparency are able to explain as much as $60.4 \%$ of the dimension.

Outer Model Analysis of the Accountability Dimension

The Outer Model (first order CFA) is defined as a model for measuring the relationships between, and the relative contributions of, each indicator of the latent endogenous variable of Accountability. The results of the estimation of the standardized loading factor parameter for Accountability in the outer model from the 5 indicators are given as follows: 
Table 6. Standardized Loading Factor Scores on the Accountability Dimension

\begin{tabular}{|c|c|c|c|}
\hline Dimension & Item & Indicator & Score \\
\hline \multirow[t]{5}{*}{ Accountability } & i1x2 & $\begin{array}{l}\text { Clarity in the function and structure of zakat } \\
\text { institutions. }\end{array}$ & 0.713 \\
\hline & $i 2 \times 2$ & $\begin{array}{l}\text { Presence of a Supervisory Board specifically } \\
\text { appointed to ensure that the zakat institution } \\
\text { complies fully with sharia, the law, and other } \\
\text { regulations. }\end{array}$ & 0.640 \\
\hline & i4x2 & $\begin{array}{l}\text { Compliance with the applicable standard of ethics } \\
\text { and values. }\end{array}$ & 0.655 \\
\hline & $i 5 \times 2$ & $\begin{array}{l}\text { Able to be responsible for every authority given to } \\
\text { every division. }\end{array}$ & 0.800 \\
\hline & i6x2 & Audit conducted by an external auditor. & 0.652 \\
\hline
\end{tabular}

Source: Output Smart PLS Version 3 (Student Version)

Table 6 shows the loading scores of the five indicators on the dimension of Accountability. It can be seen that all five indicators have a significant loading score (above 0.5). This means that they provide valid and good contributions in measuring the dimension of Accountability. The following analysis concerns the contribution made by each indicator to the dimension of Accountability:

1) i1 $x 2$ (Clarity in the function and structure of zakat institutions) contributes as much as 0.713 .

2) $12 \times 2$ (Presence of a Supervisory Board specifically appointed to ensure that the zakat institution complies fully with sharia, the law, and other regulations) contributes as much as 0.640 .

3) $14 \times 2$ (Compliance with the applicable standard of ethics and values) contributes as much as 0.655 .

4) i5x2 (Able to be responsible for every authority given to every division) contributes as much as 0.800 .

5) i6x2 (Audit conducted by an external auditor) contributes as much as 0.652 .

Regarding the dimension of Accountability, it can be seen that the indicator that contributes most is i5 2 (Able to be responsible for every authority given to every division), with a score of 0.800 . The lowest contribution is from $\mathrm{i} 2 \times 2$ (Presence of a Supervisory Board specifically assigned to ensure that the zakat institution complies fully with sharia, law, and other regulations), with a score of 0.640. Taken together, the total contribution of the five indicators in the outer model of Accountability is as much as the AVE score. Previous calculation shows that the AVE score for the dimension of Accountability is 0.582 . This means that all five indicators applied to measure the dimension of Accountability can explain as much as $58.2 \%$ of the dimension.

Outer Model Analysis of the Responsibility Dimension

The Outer Model (first order CFA) is defined as a model for measuring the relationships between, and the relative contributions of, each indicator of the latent endogenous variable of Responsibility. The results of estimating the standardized loading factor parameter for accountability in the outer model from the two indicators in the Responsibility dimension are as follows:

Table 7. Standardized Loading Factor Scores on the Responsibility Dimension

\begin{tabular}{lclc}
\hline \multicolumn{1}{c}{ Dimension } & Item & \multicolumn{1}{c}{ Indicators } & Score \\
\hline Responsibility & i1 x3 & $\begin{array}{l}\text { Availability of data and information on compliance } \\
\text { with laws and regulation (minimum violation of } \\
\text { service code of ethics). }\end{array}$ & 0.811 \\
\hline
\end{tabular}




\begin{tabular}{llc}
\hline $\mathrm{i} 2 \times 3$ & $\begin{array}{l}\text { Implementation of regular internal and external } \\
\text { audits (financial, managerial, and sharia). }\end{array}$ & 0.790 \\
\hline
\end{tabular}

Source: Output Smart PLS Smart Version 3

Table 7 shows the loading scores for the two indicators with respect to the dimension of Responsibility. It can be seen that the two indicators have significant loading scores (i.e., above 0.5), which means that they provide valid and good contributions to measuring the dimension of Accountability. The following examines the contribution of each indicator to the dimension of Responsibility.

1) i1x3 (Availability of data and information on compliance with laws and regulation (minimum violation of service code of ethics)) contributes as much as 0.811 to measuring Responsibility.

2) $i 2 \times 3$ (Implementation of regular internal and external audits (financial, managerial, and sharia)) contributes as much as 0.790 to measuring responsibility.

Regarding the dimension of Responsibility, it can be seen that the indicator with the highest contribution is i1x3 (Availability of data and information on compliance with laws and regulation (minimum violation of service code of ethics)), with a score of 0.811 . The lowest contribution is by $\mathrm{i} 2 \times 3$ (Implementation of regular internal and external audits (financial, managerial, and sharia)), with a score of 0.790 . Taken together, the total contribution of the two indicators in the outer model of Responsibility is as much as the AVE score. Previous calculation showed that the dimension of Responsibility has an AVE score of 0.641. This means that the two indicators applied to measure Transparency can explain as much as $64.1 \%$ of the dimension.

Outer Model Analysis of the Independence Dimension

The Outer Model (first order CFA) is defined as a model for measuring the relationships between, and the relative contributions of, each indicator of the latent endogenous variable of Independence. The results for the estimation of the standardized loading factor parameter on the Independence dimension in the outer model from the two indicators are as follows:

Table 8. Standardized Loading Factor Scores on the Independence Dimension

\begin{tabular}{|c|c|c|c|}
\hline Dimension & Item & Indicator & Score \\
\hline \multirow[t]{3}{*}{ Independence } & i1x 4 & $\begin{array}{l}\text { Professional management of zakat } \\
\text { institutions. }\end{array}$ & 0.704 \\
\hline & $\mathrm{i} 2 \mathrm{x} 4$ & $\begin{array}{l}\text { No pressure from unauthorized parties } \\
\text { based on existing regulations. }\end{array}$ & 0.743 \\
\hline & $i 3 \times 4$ & $\begin{array}{l}\text { Objective and independent decision- } \\
\text { making, free from pressure or intimidation } \\
\text { from any party. }\end{array}$ & 0.744 \\
\hline
\end{tabular}

Source: Output Smart PLS Version 3 (Student Version)

Table 8 shows the loading scores for the three indicators on the dimension of Independence. It can be seen that each of the indicators has a significant loading score (i.e., above 0.5), thus indicating that they provide valid and good contributions in measuring the dimension of Independence. The following is an analysis of each indicator's contribution to the dimension of Independence. 
1) i1x4 (Professional management of zakat institutions) contributes as much as 0.704 .

2) $i 2 \times 4$ (No pressure from unauthorized parties based on existing regulation) contributes as much as 0.743 .

3) i3x4 (Objective decision-making, free from pressure or intimidation from any party) contributes as much as 0.744 .

Regarding the dimension of Independence, it can be seen that the indicator with the greatest contribution is i3x4 (Professional management of zakat institutions), with a score of 0.743 . The lowest contribution comes from ilx4 (No pressure from unauthorized parties based on existing regulations), with a score of
0.704. When taken together, the total contribution of the three indicators in the outer model of Independence is as much as the AVE score. Previous calculation revealed the AVE score for the dimension of Independence to be 0.533 . This means that the three indicators applied to measure the dimension of Independence can explain as much as $53.3 \%$ of the dimension.

Based on the data processing conducted using Smart PLS version 3 software, it can be concluded that the factors that lead to the establishment of good governance in zakat institutions, along with their indicators and contributions, are capable of measuring/evaluating good governance in zakat institutions, as described in Table 9.

Table 9. Factors for the Establishment of Good Governance in Zakat Institutions and their Contributions

\begin{tabular}{|c|c|c|}
\hline Construct & Contribution of Highest Indicator & Contribution of Lowest Indicator \\
\hline Transparency & $\begin{array}{l}\text { i4x1 (Availability of information on } \\
\text { the amount of funds collected) } \\
\text { contributes } 0.848 \text { to the dimension of } \\
\text { Transparency. }\end{array}$ & $\begin{array}{l}\text { i7x1 (Availability of financial reports } \\
\text { (collection, distribution, utilization)) } \\
\text { contributes } 0.778 \text { to the dimension of } \\
\text { Transparency. }\end{array}$ \\
\hline Accountability & $\begin{array}{l}\text { i5x2 (Able to be responsible for every } \\
\text { authority given to every division) } \\
\text { contributes } 0.800 \text {. }\end{array}$ & $\begin{array}{l}\text { i2x2 (Presence of a Supervisory Board } \\
\text { specifically appointed to ensure that the } \\
\text { zakat institution complies fully with } \\
\text { sharia, the law, and other regulations) } \\
\text { contributes as much as } 0.640 \text {. }\end{array}$ \\
\hline Respons & $\begin{array}{l}\text { i1x3 (Availability of data and } \\
\text { information on compliance with laws } \\
\text { and regulations (minimum violation } \\
\text { of service code of ethics)) contributes } \\
\text { as much as } 0.811 \text { to measuring } \\
\text { Responsibility. }\end{array}$ & $\begin{array}{l}\text { i2x3 (Implementation of regular } \\
\text { internal and external audits (financial, } \\
\text { managerial, and sharia)) contributes } \\
0.790 \text { to the measurement of } \\
\text { Responsibility. }\end{array}$ \\
\hline Independence & $\begin{array}{l}\text { i3x4 (Objective and independent } \\
\text { decision-making, free from pressure } \\
\text { or intimidation from any party) } \\
\text { contributes } 0.744 \text {. }\end{array}$ & $\begin{array}{l}\text { i1x4 (Professional management of } \\
\text { zakat institutions) contributes } 0.704 \text {. }\end{array}$ \\
\hline
\end{tabular}

Source: Output Smart PLS Version 3 (Student Version)

\section{CONCLUSION}

Good governance is a crucial issue in the context of strengthening the performance of zakat institutions. CFA was conducted to evaluate the contribution of each indicator to the five principles of good governance in zakat institutions, namely transparency, accountability, responsibility, independence, and fairness. With the assistance of Partial Least Squares (PLS) version 3, it has been shown that the principle of transparency contributes $60.4 \%$; the principle of accountability $4.82 \%$; the principle of responsibility $6.41 \%$; and the principle of independence $53.3 \%$. It has been demonstrated that these four factors are able to measure/evaluate GCG in zakat institutions and to evaluate 
the lowest and highest contributions from their respective indicators.

First, the highest contribution in transparency is $\mathrm{i} 4 \mathrm{x} 1$ (Availability of information on the amount of funds collected) that contributes as much as 0.848 , while the lowest contribution is $i 7 \mathrm{x} 1$ (Availability of financial reports (collection, distribution, utilization)), which contributes 0.778. Second, the highest principle in accountability is $\mathrm{i} 5 \mathrm{x} 2$ (Able to be responsible for every authority given to every division), which contributes 0.800 , while the lowest contribution is $12 \times 2$ (Presence of a Supervisory Board specifically appointed to ensure that the zakat institution complies fully with sharia, the law, and other regulations), which contributes 0.640. Third, the highest contribution in responsibility is $\mathrm{i} 1 \mathrm{x} 3$ (Availability of data and information on compliance with laws and regulations (minimum violation of service code of ethics)), which contributes 0.811 , and the lowest contribution is $i 2 \times 3$ (Implementation of regular internal and external audits (financial, managerial, and sharia)), which contributes 0.790 . Fourth, the highest contribution in independence is i3 44 (Objective decision-making, free from pressure or intimidation from any party), which contributes 0.744 , and the lowest contribution is i1x4 (Professional management of zakat institutions), which contributes 0.704 . Therefore, it can be concluded that good governance in zakat institutions has been well implemented in certain aspects but has yet to be implemented comprehensively. This research is significant in that it contributes guidelines on zakat management, provides teaching materials for higher education, and serves as a reference for formulating policies and regulations related to the standardization of good governance in zakat institutions.

\section{REFERENCES}

Abdillah, W., \& Jogiyanto. (2015). Partial least square (PLS) alternatif structural equation modeling (SEM) dalam Penelitian Bisnis. Yogyakarta:

CV.Andi Yogyakarta.

Abu-Tapanjeh, A. M. (2009). Corporate governance from the Islamic perspective: A comparative analysis with OECD principles. Critical Perspectives on accounting, 20(5), 556-567.

Bariyah, N. O. (2010). Kontekstualisasi Total Quality Management Dalam Lembaga Pengelola Zakat Untuk Pemberdayaan Ekonomi Masyarakat (Prinsip dan Praktik). Disertasi: SPS UIN Jakarta.

Beik, I. S. (2009). Analisis Peran Zakat dalam Mengurangi Kemiskinan: Studi Kasus Dompet Dhuafa Republika. Jurnal Zakat \& Empowering, Pemikiran dan Gagasan, II(hlm.10).

Bhatti, M., \& Bhatti, I. (2009). Development in legal issues of corporate governance in Islamic Finance. Journal of Economic \& Administrative Sciences, 25(1), 67-91.

http://www.emeraldinsight.com/d oi/abs/10.1108/102641162009000 04

Bhatti, M., \& Bhatti, M. I. (2010). Toward understanding Islamic corporate governance issues in Islamic finance. Asian Politics \& Policy, 2(1), 25-38.

Chapra, M. U., \& Habib, A. (2002). Islamic governance in Islamic financial institutions. Jeddah: IRTI IDB, pp. 50-71.

Grais, W., \& Pellegrini, M. (2006). Corporate governance in institutions offering Islamic financial services: Issues and options. World Bank Policy 
Research Working Paper 4052, November 2006.

Harrington, D. (2009). Confirmatory factor analysis. Oxford: Oxford University Press.

Hasan, Z. (2009). Corporate governance: Western and Islamic perspectives. International Review of Business Research Paper, 5(1), 277-293. https://www.bizresearchpapers.co m/attachments_2009_01_13/23.Z ulkipli.pdf

Hermawan, A. (2003). Pedoman Praktis Metodologi Penelitian Bisnis. Jakarta: LPFE Trisakti.

Issyam, M., Hasan, R. bt, \& Alhabshi, S. M. (2016). Sharia governance framework for Islamic cooperatives as an integral social institution in Malaysia.

Intellectual Discourse Journal, Special Issue, 2016, 477-500.

Retrieved from: https://search.proquest.com/openv iew/7301707d8c3bafef85c730cb9 a65b312/1?pqorigsite $=$ gscholar\&cbl $=826340$

Jahar, A. S.(2008). Zakat antar bangsa Muslim: Menimbang posisi realistis pemerintah dan organisasi masyarakat sipil. Jurnal Zakat \& Empowering, Pemikiran dan Gagasan, 1(4), hlm.16.

Kaslam, S. (2011). Governing zakat as a social institution: The Malaysian perspective. International Journal of Governance, 1(2), 282-294.

Lewis, M. K. (2006). "Accountability and Islam", Conference Paper presented at Fourth International Conference on Accounting and Finance in Transition Adelaide, April 10-12, 2006. Source: http://search.ror.unisa.edu.au/reco rd/UNISA_ALMA111433551600 01831/media/digital/open/991591 $1835001831 / 12143355150001831$ $/ 13143350630001831 / \mathrm{pdf}$

Mansoer, M. (2009). Statistik sosial. Jakarta: Ushul Press.
Mansoor, K. M., \& Bhatti, I. M. (2008). Development in Islamic banking: a financial risk-allocation approach. The Journal of Risk Finance, 9(1), 40-51.

Pedoman Umum Good Corporate Governance di Indonesia, dikeluarkan oleh Komite Nasional Kebijakan Governance (KNKG), 2006.

Peraturan Bank Indonesia No. 11/33/PBI/2009 Tentang Pelaksanaan Good Corporate Governance Bagi Bank Umum Syariah Dan Unit Usaha Syariah Pasal 1 ayat 10.

Ramli, N. M., \& Muhamed, N. A. (2013). Good governance framework for corporate waqf towards accountability enhancement. Proceeding of World Universities Islamic Philanthropy Conference 2013. Source: https://papers.ssrn.com/sol3/paper s.cfm?abstract_id $=2437260$

Safieddine, A. (2009). Islamic financial institutions and corporate governance: New insights for agency theory. Corporate Governance: An International Review, 17(2), 142-158.

Samra, E. (2016). Corporate governance in Islamic financial institutions.

Sarwono, J., \& Narimawati, U. (2015). Membuat Skripsi, Tesis dan Disertasi Partial Least Square SEM. Yogyakarta: CV. Andi Yogyakarta.

Sedarmayanti. (2007). Good Governance (Kepemerintahan yang Baik) dan Good Corporate Governance (Tata Kelola Perusahaan Yang Baik.). Bandung: CV. Mandar Maju.

Siddiqi, S., Masud, T. I., Nishtar, S., Peters, D. H., Sabri, B., Bile, K. M., \& Jama, M. A. (2009). Framework for assessing governance of the health system in developing countries: Gateway to good 
governance. Health policy, 90(1), 13-25.

Sudibyo, B. (2016). Zakat Dapat Jadi Pilar Terbangunnya Martabat Umat, dalam Artikel Majalah Mulia, Edisi Februari 2016.

Sundararajan, V., \& Errico, L. (2002). Islamic financial institutions and products in the global financial system: Key issues in risk management and challenges ahead (Vol. 2). International Monetary Fund.

Undang-Undang No. 23 Tahun 2011 tentang Pengelolaan Zakat.

Undang-Undang No. 38 Tahun 1999 tentang Pengelolaan Zakat.

Wahab, N. A., \& Abdul Rahim, A. R. (2011). A framework to analyse the efficiency and governance of zakat institutions. Journal of Islamic Accounting and Business Research, 2(1), 43-62. Retrieved from:

http://www.emeraldinsight.com/d oi/abs/10.1108/175908111111295 08

Wahab, N. A., \& Abdul Rahim, A. R. (2011). A framework to analyse the efficiency and governance of zakat institutions. Journal of Islamic Accounting and Business Research, 2(1), 43-62.

Wibisono, Y. (2016). Peluang Zakat Nasional (Peluang dan Tantangan) Pengelolaan Zakat di Indonesia," makalah disampaikan dalam Seminar Nasional Refleksi Pengelolaan Zakat Nasional, diselenggarakan oleh PUZKAZ BAZNAS dan FEBS Universitas Indonesia, 8 Desember 2016.

Hani Tahliani

PT Pendidikan Maritim \& Logistik Indonesia

(IPC Corporate University)

hani10972@gmail.com 